\title{
Rethinking Avenues to Resolve North Korean Nuclear Issues: Bilateral Relations or Multilateral Coordination?
}

\author{
Fahua Qiu \\ School of Marxism, University of Shanghai for Science and Technology, Shanghai, China \\ Email: fhqiu@126.com
}

How to cite this paper: Qiu, F. H. (2021). Rethinking Avenues to Resolve North Korean Nuclear Issues: Bilateral Relations or Multilateral Coordination? Open Journal of Political Science, 11, 155-168. https://doi.org/10.4236/ojps.2021.111010

Received: December 28, 2020

Accepted: January 24, 2021

Published: January 27, 2021

Copyright $\odot 2021$ by author(s) and Scientific Research Publishing Inc. This work is licensed under the Creative Commons Attribution International License (CC BY 4.0).

http://creativecommons.org/licenses/by/4.0/

\section{(c) (i) Open Access}

\begin{abstract}
Since the easing trend of the situation of the Korean peninsula in 2018, active and positive changes have occurred in the bilateral relationship between North Korea and South Korean/the US/China as well as between China and South Korea. In this scenario, the bilateral relationship between North Korea and South Korea or the US has been considered to be the main avenue to resolve the North Korean nuclear issues. However, in essence, the formation and development of the North Korean nuclear issues are the consequences of the multilateral factors, which also embody the limitations of the bilateral relations of North Korea and the US/South Korea. The future complete resolution of the North Korea nuclear issues should be dependent on the framework of multilateralism driven by the bilateral relations.
\end{abstract}

\section{Keywords}

North Korean Nuclear Issues, Bilateral Relations, Multilateral Coordination

\section{Introduction}

Since the breakout of the North Korean nuclear crisis, the situation of the Korean peninsula has been tangled by the complex bilateral and multilateral relationship of the related nations. In particular, the tension of the North Korea-US relationship has been eased to some extent following the presidential meeting between Kim Jong-un and Donald Trump in the year of 2018. This proposes such a possibility that the resolution of the North Korean nuclear issues is seemingly dependent sorely on the bilateral relations between North Korea and the US, of which the viewpoint has been preached by the overseas press. However, the second presidential meeting between Donald Trump and Kim Jong-un (Feb. 
$28,2019)$ did not produce any signed agreement between the US and North Korea, throwing an uncertain shadow on the way of resolving the North Korean nuclear issues. Thereafter, there still exists a tendency of tension of the situation in the Korean peninsula despite that the two parties of the US and North Korea leave a space for the bilateral dialogue. In reality, after the bilateral talk in Sweden in October, 2019, the US and North Korea gave up to the expectation to each other, leading to another diplomatic confrontation between the two nations at the end of the year 2019.

\section{Research Methodology}

In this context, it is of importance and interest to ask whether it is enough for the bilateral relations of the US and North Korea to reach an agreement to resolve the North Korean nuclear issues. Why does the North Korea-US relationship, which has been given great expectations in 2018 by the International societies, take a sudden turn for the worse? Does the multilateralism framework still play a role in resolving the nuclear crisis in the Korean Peninsula, and what about the role of China therein? I will follow a logical framework analysis shown below. Firstly, the situation of the Korean Peninsula has presented a bilateral characteristic, especially embodied in the two variables of the North Korea-South Korea and North Korea-the US relationships. This tendency and the underlying causes have been analyzed. Second, the author considers the multilateral factors as the essence and source leading to the outbreak of the North Korean nuclear issues. It is thus fundamental to be within the multilateral framework to overcome the North Korean nuclear issues. Thirdly, the role of bilateralism and multilateralism in resolving the North Korean issues has been intertwined by their mutual facilitation and mutual impediment. On the one hand, a good bilateral relationship is the basis for the multilateral cooperation. On the other hand, the disparity of the nature of the bilateral relations surrounding the Korean peninsula is, to some extent the obstacle leading to no result of the multilateral cooperation. Therefore, the avenue of the replacement of armistice with a peace treaty in parallel tracks proposed by China is one choice to resolve North Korean nuclear issues via the multilateral cooperation based on the development of the bilateral relations.

\subsection{The Bilateral Characteristics of the Development of the Situation in the Korean Peninsula}

Since the year of 2018, active and positive changes have occurred for the situation of the Korean peninsula, with more mutual interactions between North and South Korea in the Peninsula such as the Summit of the two sides of Korea, the sign of the Panmunjom Declaration, the reunion of separated families and the mine removal near the $38^{\text {th }}$ parallel. In particular, the mediation of South Korea brings forward a giant progress of the North Korea-US relations, characterized by the successful realization of the two summits of the North Korea and US in 2018 and 2019, respectively. Especially in the Summit of the US and North Ko- 
rea in 2019, President Donald Trump crossed the $38^{\text {th }}$ parallel and made a historic hands-shake with the supreme leader of North Korea, Kim Jong-un. The leaders shook hands on the North Korean side of the DMZ, making President Donald Trump the first sitting American president to ever set foot in the hermit state, before crossing together to the South Korean side and shaking hands again (Turak, 2019). Meanwhile, besides the obvious improvement of the US-North Korean relations, there is a good interactive trend in the Sino-North Korea/South Korea relationship, with a strong bilateral characteristic.

Firstly, from the perspective of the inner geopolitical structure, appeasing the bilateral relations of North and South Korea has largely reduced the tense situation of the Peninsula.

Geopolitically, the Korean peninsula has been a sphere of influence struggled by great powers due to its important geographical position since ancient times. Since the establishment of their respective regimes by North and South Korea after the end of World War II, the relationship between North and South Korea has been the barometer reflecting the competitive situation of the USA and Soviet during the cold war. In this scenario, successive South Korean governments have taken different policies towards North Korea, leading to a clock pendulum-like change with tension and appease of the relationship of North and South Korea. Dramatic transitions from the tensive situation in 2017 to the appeasing situation in 2018 have occurred in the relationship of North and South Korea, being a natural consequence of the joint efforts of the four related parties including North Korea, the US, South Korea and China on the Korean peninsula. In this regard, the virtuous interaction between North and South Korea is the predominant engine in facilitating the progress of the situation of the Korean peninsula (Zheng, 2018). A time pipeline can be followed below: releasing goodness by North and South Korea during the winter Olympics in Pyeongchang in 2018, realization of summit meeting between North and South Korea on April 27, May 26 and September 18-20. During the summit, both Kim Jong Un and Moon Jae-in repeatedly stressed that the fate of the Korean peninsula should be grasped in Korean people. And two important documents, "the Panmunjom Declaration for Peace, Prosperity and Unification of the Korean Peninsula" and "Pyongyang Joint Declaration", were signed by the two Korean leaders, which reached a consensus in easing the military tension on the Peninsula, eliminating the war threat in the Peninsula, expanding communication and cooperation, developing a balanced national economy and establishing a permanent and firm peace regime. In parallel, North and South Korea took actual measures to show their mutual goodness for communication. For example, North Korea dismantled the nuclear test site in Punggyeri on May 24, 2018. The military on both sides started mutual examination on the clearance of sentry posts in the de-militarized zone from December 12, 2018. The two sides of Korea held a commencement ceremony of the railway and highway connection project of North and South Korea on December 26, 2018.

According to these events, it is obvious that the appease of the North-South 
Korean relationship not only pulls the Korean peninsula back from war fringe but also jointly facilitated the realization of the summit meeting of North Korea and the US and eradicated the external tense environment. It is thus reasonable to infer that the most predominant driving force for the transition of the situation of the Korean peninsula is derived from the internal factor, i.e. the changes of the bilateral relations between North and South Korea. On the basis of the "sunshine policy" by Kim Dae Jung and the "peaceful and prosperous policy" by Roh Moon Hyun, President Moon Jae-in tried to use the sunshine policy and toleration to North Korea to induce its possible changes. However, the policy to North Korea by Moon Jae-in led to an appeasement of the North-South Korean relationship, it still took some risks and was opposed by some population. In their viewpoints, no matter what the post payment system of the economic and political connections (emphasizing the denuclearization consequence) or the prepayment system of the economic and political segregation (emphasizing the denuclearization process) produced a quite limited effect on the denuclearization of North Korea, thereby being considered as an immature policy (Gu, 2019). In fact, with the sudden turn for the worse of the US-North Korean relations at the end of 2019, the two sides of Korea tend to show tensions in the bilateral relations.

Secondly, based on the key variable of the geopolitical structure, the realization of the summit meeting of North Korea and the US showed a characteristic of the North Korea-US bilateral relationship affecting the trend of the situation on the Korean peninsula.

Since the end of the cold war, North Korea and the US have long been in a hostile state. The nuclear crisis of the Korean peninsula further aggravates the US-North Korean security dilemma. In particular, Donald Trump abandoned Obama's "strategic patience" policy after he came into power in 2017 and turned to take "extreme oppression" policy to deal with North Korea, which mobilized almost all international support to execute stringent sanction against and isolation of North Korea (Zhu, 2018). This has been considered to be the main reason leading to the transition of North Korea's attitude on the nuclear issues. For instance, there occurred an abnormally intense diplomatic spat in 2017 between North Korea and the US. However, this situation changed in 2018, characterized by the realization of the summit meeting of Donald Trump and Kim Jong Un on June 12. This meeting has been considered as a milestone event in the history of North Korea and the US, in which the two sides reached a consensus and issued a joint statement in four aspects including the establishment of new US-North Korea relations, the building of a lasting and robust peace regime on the Korean peninsula, denuclearization of the Korean peninsula and repatriation of identified prisoner of war (POW)/missing in action (MIA) remains. This statement stipulates the principle and points a direction to solve the Korean nuclear issues. Right within the framework of the Statement, the second North Korea-US summit was held in Ha Noi on Feb. 28, 2019. Due to the inconsistent expectations of 
North Korea and the US in denuclearization and lifting international sanctions, there were no signed agreements in this Summit. On the one hand, it is unacceptable for the US to sign a declaration to end the Korean war. There is no possibility for the Trump administration to lift sanctions against North Korea or to cease the military oppression on North Korea. In fact, Trump won't change the "extreme oppression" policy for North Korea before resolving the nuclear issues (Teng, 2018). Therefore, in spite of the expectation held by North Korea and the US for the future, there is no sign of compromise in some key issues such as denuclearization and lifting sanctions, implying that the trend of the situation on the Korean peninsula is largely influenced by the bilateral relations of the US and North Korea.

In fact, the US-North Korea bilateral relation is in essence asymmetrical, but the difference in power structure between the US and North Korea was neutralized by factors such as the Juche Idea of North Korea and the competitive yet lethargy economy and regime legitimacy of South Korea. These factors enhanced the capability of North Korea to balance the pressure from the US (Park, 2010). Still the Washington administration continues to demand that Pyongyang relinquish the nuclear weapons it already has, and the Trump administration has pledged that the North Korean regime will never acquire a nuclear missile that can hit the United States (Jervis \& Rapp-Hoope, 2018). According to the asymmetric theory, the disparity in attention information between great power and small state can, at least in part neutralize the asymmetry in power material, thus producing a practical influence on the agenda and consequences of the bilateral relations. There exists an asymmetrical relationship in power between the US and North Korea, in which different concerns and wrong feelings easily evoke a worsening perception and lead to an escalating conflict between the two nations. During that process, North Korea becomes more active and powerful due to its asymmetrical relationship with the US while the US cannot determine the conditions of its relations with North Korea on one side. In particular, the occurrence of North Korean nuclear issues puts the US-North Korea relationship in a cycle of tension-conflict escalation-crisis management (Zhang, 2019). Actually, as the superpower, the US puts the asymmetrical relationship on any nations it deals with, even the past Soviet Union or today's China. Due to the huge gap in economic and military power, the US-North Korea relationship is surely asymmetrical. Because of that, the asymmetrical relationship of the US and North Korea fell again in a crisis of tension at the end of 2019, demonstrating the possibility of the US-North Korea relations being trapped in the vicious cycle.

Thirdly, in view of the external structure of geopolitics, the bilateral relations of China and North KorealSouth KorealJapan all keep a good momentum with varying degrees.

As neighbors of the Korean peninsula, China and Japan have countless links with the Peninsula. Thus, it is utmost important of the bilateral relations of the related nations surrounding the Peninsula with Korea for the trend of the situa- 
tion on the Korean peninsula.

Due to the historical and realistic reasons, much attention has been focused on the Sino-North Korea relationship. As far as China is concerned, it was put in an awkward position in the situation of the Korean peninsula in 2017. Due to the nuclear tests by North Korea and the pressure of the international community, China had to join the sanctions against North Korea imposed by the United Nations, thereby cooling down the Sino-North Korea relationship. China has vehemently criticized the DPRK. In addition, it voted for UN Security Council resolutions that imposed strict sanctions on Pyongyang. China even imposed its own sanctions against the DPRK (Kim, 2017). As for the Sino-North Korea relationship, it has entered a new historical era after the first visit of North Korea by Chinese leader Xi Jinping (June 20-21, 2019). With the promotion of the Sino-North Korea relations, both the leaders reemphasize the maintenance of the traditional friendship, restore and consolidate the foundation of the friendship and cooperation as well as strengthen the strategic communication about the trend of the Korean peninsula (Li, 2019). The resurrection of China-North Korea's relations primarily stem from the distrust towards North Korea by the US, which necessitates a third power to balance the unbalanced US-North Korea-South Korea relationship. However, some researchers have pointed out that the reasons that the US-North Korea meeting produced no agreements are exactly due to the resurrection of the relations between China and North Korea. This viewpoint is apparently not the truth, for that China wishes more eagerly to see any deals regarding denuclearization of the Korean peninsula signed by the two parties of the US and North Korea. Some may also argue that the betterment of the China-North Korean relations might loosen China's attitudes of sanctions against North Korea. However, we should see that China has taken a firm stance to support the resolution of sanctions against North Korea right after the $6^{\text {th }}$ nuclear test by North Korea. Also it is the truth that China has also maintained a film position that sanctions should be focused on deterring North Korea's nuclear development, and should not induce any harmful results to North Korean residents" daily lives or normal state-relations and humanitarian aids (Jun, 2017).

Also, the THAAD incident hindered the development of the Sino-South Korea relationship. However, the situation has changed after the visit of China by Moon Jae-in (2017) and Kim Jong-un (2018). Accompanying this, the Sino-South Korea relationship has been warmed up and the Sino-North Korea relationship has been consolidated and promoted. The combination of New North Policy by President Moon Jae-in with the Belt and Road Initiative of China draws a closer connection of the Sino-South Korea relations. The two nations have the common consensus in resolving the North Korea nuclear issue and the peace in Northeast Asia, being the foundation of the Sino-South Korea cooperation. As for Japan, the visit of China by Abe Shinzo in 2018 gets the Sino-Japan relations back to the normal orbit. The warming Sino-Japan relationship also 
promotes the multilateral cooperation in Northeast Asia. During the Summit of China, Japan and South Korea in Chengdu city (Dec. 24, 2019), there is a consensus that the realization the denuclearization of the Korean peninsula and the establishment of peace mechanism conforms to the common interest of the three nations. They decide to push forward the dialogue to make progress, handle carefully the reasonable concerns of the related parties, propel the political resolution of the Peninsula issues and realize the regional long period peace and stability. According to these facts, it can be seen that the ease of the series of the bilateral relations provides a relaxed external environment for the development of the situation of the Korean peninsula, thereby making it possible for the cooperation of the related parties to solve the issues of the peninsula.

Generally, the bilateral relations are the touchstone of the development of the situation on the Korean peninsula, which determines the degree of the tension of the situation on the Peninsula. It goes without any doubts that the active changes of the bilateral relations surrounding the Korean peninsula since the year of 2018 indeed ease the tension of the situation of the Peninsula. One may ask whether these changes of the bilateral relations can completely solve the Korean nuclear issues. In view of the crises ridden in the situation of the Korean peninsula following the sudden turn for the worse of the US-North Korea relationship since the year of 2019, it implies that it is far from enough for the active changes of the bilateral relations to completely resolve the North Korean nuclear issues. The author views that the nuclear issues of the Korean peninsula are caused by the multilateral games in essence, which is unlikely to be solved sorely by the bilateral avenue.

\subsection{The Multilateral Nature of the North Korea Nuclear Issues}

In international relations "multilateralism" has been depicted more as a generic institutional form. As pointed out by John Gerard Ruggie, multilateralism is an institutional form, by which relations among three or more nations are coordinated in accordance with generalized principles of conduct. In addition, multilateralism in international relations is mainly represented as a behavioral mode among state actors as well as the emphasis on and abidance by the generalized norms and rules. As a social arrangement aiming to develop a good interaction between state actors, multilateralism is endowed with the basic characteristics of coordination and cooperation. However, the approach tried so far has eschewed the use of trade restrictions, but it has also been ineffective. Ironically, this has made the trade system more vulnerable (Barrett, 2011). Considering the awkward situation of multilateralism in dealing with issues in economy and trade, it is no wonder that there would be more difficulties and obstacles to use multilateral mechanism to resolve the safety issues of advanced politics. As aforementioned, geopolitically the Korean nuclear issues are not the consequence of the mutual construction of the sore bilateral relations. It is the fundamentally combined consequence of the multilateral relations that leads to the formation and 
development of the Korean nuclear issues. Surely the word "multilateralism" here implies more the struggling of their strategic interests of the related nations in the Korean peninsula. It can be thereby concluded in a logical way that it is the multilateral factors that lead to the outbreak of the North Korean nuclear issues while at the same time the eventual resolution of the Korean nuclear issues is rooted in a multilateral mode. So a regional approach to international cooperation and suggests that a regional security arrangement should be established in Northeast Asia to resolve the North Korean nuclear crisis (Ko, 2019).

From the perspective of historical logic, the geopolitical position of the Korean peninsula determines the predominance of the development of the situation of the Peninsula by the multilateral factors.

In history, the Korean peninsula was always the competition place of great powers. Japan and Russia fought for the peninsula in 1905. The Korean War during the cold war is represented as the regional hot war of the US-Soviet hegemony. These changes including the Korean division after World War II are all caused by the multilateral factors. With the execution of the pragmatic diplomacy policy after the cold war, China tries to maintain the equilibrium policy on the Korean peninsula after its establishment of diplomatic relations with South Korea, i.e., keeping the traditional friendship with North Korea and simultaneously having economic and trade cooperation with South Korea. However, the breakout and continuous development of the Korean nuclear crisis not only challenge the peripheral security of China, but also put China's policy on the Peninsula in an awkward situation. From the year of 2003 to 2009, the three-party, four-party and six-party talks endowed the situation of the North Korean nuclear issues with strong multilateral characteristics. However, Kim Jong Il declared in April 2009 that North Korea would retire forever from the six-party talk mechanism, thereby leaving the situation of the Korean peninsula in a state of out of control or divergence. With the growth of China's might since 2010, the Korean nuclear issues have been used as excuses by the US to contain China, in which the US recasts its alliance with South Korea and Japan, damages the Sino-South Korea relationship, breaks the equilibrium of the might in East Asia, deploys the THAAD system and weakens the ability of China's nuclear deterrence (Han, 2018). With the deepening of the Sino-US strategic game, the trend of the Korean peninsula's situation cannot be predominated by the two sides of North and South Korea but by the complex multilateral game of the related nations. In fact, in dealing with the future issues of the Korean peninsula, the development of the Sino-US relations and the transit of the China's diplomatic direction have been the crucial variables. The North and South Korea are the important neighbors of China, which forms a natural cooperation foundation of the three nations. Thus, the development and changes of the Sino-North Korea-South Korea relationship will become the important foci in Northeast Asia (Lee \& Piao, 2019). According to these facts, it can be inferred that the development of the situation of the Korean peninsula is in essence the consequence of 
the joint forces of the multilateral relations.

In the case of the formation of the Korean nuclear crisis, it is the consequence of the complex game of the multilateral relations.

The related parties surrounding the Korean peninsula, North and South Korea and their peripheral great powers including China, the US, Japan, Russia constitute the regional international relation system (Piao, 2014). Since this system is composed of multiple parties, the formation of the Korean nuclear issues is the consequence of the multilateral relations' game. After the end of the cold war, China and the Soviet Union established diplomatic relations with South Korea. However, the US and Japan did not break the Cold War mentality and realize their cross recognition with North Korea. Based on its own national safety, for years Pyongyang has requested a non-aggression pact as well as bilateral negotiations with the US, leading to a normalization of the relationship between the two countries, or at least to a recognition of each other's sovereignty. So North Korea has to rush into danger and pursue nuclear-armed self-protection. Therefore, the purposes why North Korea develops nuclear weapons are very specific and clear: to self-protect and to defy orders with armed nuclear weapons. With these nuclear weapons, it can give North Korea a safe feeling to safeguard the safety of its socialist regime, to enhance its strategic role in the regional security pattern and to raise its strategic weight with the US in the game-dialogue-cooperation process (Yang, 2019). Although the Korean nuclear issue is often ascribed to the worsening North Korea-US relationship, it is fundamentally the consequence of the strategic games of the multiple nations in the regional international relation system. The hostility toward North Korea by the US, Japan and South Korea and the lack of security from China and Russia led to the eventual pursuit of nuclear by North Korea for its safety.

From the development of the situation on the Korean peninsula, the multilateral game is characterized in the process of resolving the nuclear issues.

After the breakout of the Korean nuclear crisis, the US-North Korea bilateral negotiation tried and failed. Then as multilateral security mechanism was successively introduced, including the US/North Korea/South Korea three-party talk, the Sino/US/North Korea/South Korea four-party talk and the Sino/US/North Korea/South Korea/Japan/Russia six-party talk. The six-party talk was finally held great expectations and reached the 9.19 joint statement, being considered as a good opportunity of resolving the Korean nuclear issues. However, due to the serious disparity in the procedures of "action for action" of the US and North Korea and subsequent crisis escalation, the six-party talk ended up in failure with the quit of the talk by North Korea. The academia ascribed the failure of the six-party talk to too many variables involved, revealing the complexity of the multilateral game in the six-party talk mechanism. Actually, in the historical process of resolving the Korean nuclear issues, debates are always put on the feasibility of the bilateral mechanism or multilateral one. In the aspect of the pragmatic operation, the bilateral and multilateral modes are also tried. For 
example, as far as the international sanctions advocated by the US against North Korea to resolve the nuclear issues, the multilateral cooperation of the international society is necessary to warrant the sanction results. Since 2018 North Korea has executed an unprecedented peace offensive, of which the aims are to break up the conformed policies towards North Korea taken by China, the US, Russia and South Korea through some operations of freezing the nuclear plans, and thereby substantially mitigate sanctions. In consequence, there exists a certain chasm in the policies towards North Korean taken by the US and South Korea/other related nations (Jin, 2019). A paradox exists in the mode of resolving the North Korea nuclear issues. On the one hand, the international society has given a highly expectation of the US-North Korea bilateral relations. On the other hand, the international society also stresses that all related nations should take a concerted step to cooperate with the UN Security Council for the sanctions against North Korea. The fact that the summit of the US and North Korea on February 28, 2019 did not produce any diplomatic achievements implies that it is impossible to completely solve the Korean nuclear issues sorely by the US-North Korea bilateral relations. Apparently, the bilateral parties of the US and North Korea are also the key link in the game of the multilateral powers. The fundamental hostility and conflict rooted in the two nations has been an obstacle to impede the establishment of the multilateralism mechanism in Northeast Asia.

The history tells us that the development of anything is not single and linear, but a dynamic process of the complex game of the multilateral factors. As Engels put it, history is made in such a way that the final result always arises from conflicts between many individual wills, of which each in turn has been made what it is by a host of particular conditions of life. Thus there are innumerable intersecting forces, an infinite series of parallelograms of forces which give rise to one resultant-the historical event. The formation, development and eventual resolution of the Korean nuclear issues cannot be determined only by several bilateral relations. The multilateral essence reveals that the coordination and cooperation of the related parties are the sole avenue to completely resolve the nuclear issues.

\subsection{Rethinking the Avenues to Resolve the Nuclear Issues in the New Situation}

In the new situation we cannot count on the bilateral relations of the North Korea and South Korea/the US to fully resolve the nuclear issues in the Korean peninsula. Meanwhile, it is also inappropriate to put the multilateral cooperation, as shown in the six-party talks, as a bargaining platform to earn the individual strategic interest. We should take measures to keep promoting the bilateral relations of the North Korea and the US/South Korea for the good development and simultaneously establish a platform of multilateral negotiation including the US, North Korea, South Korea and China as the warranty of the bilateral relations. 
The bilateral relations such as the North Korea-South Korea and North Korea-US relationship are still the prerequisite and foundation of easing the situation of the peninsula and resolving the nuclear issues.

It is true that the ease of the North-South Korean relationship has produced a relaxation of the tension state of the situation of the Korean peninsula, which can be further consolidated by the benevolent governmental interaction and the deepening non-governmental exchanges of both sides of Korea. As for the US-North Korea bilateral relationship, it has already represented a huge breakthrough from initial hostility to later contact in spite of the setback encountered. At the end of 2019, the US-North Korea relations fell into a deadlock and there was even an armed standoff between the two sides at the advent of the deadline for North Korea. In the face of this situation, China appealed that "We hope the UN Security Council can have one voice in supporting the political settlement of the issue. The UN Security Council should encourage the United States and the DPRK to respect each other's concerns, show flexibility and sincerity, meet each other halfway, make joint efforts to implement the consensus of the Singapore Joint Statement, follow the phased and synchronized principles to resume dialogue as soon as possible, and prevent the dialogue process from derailing or even regressing. It won't be far from the absolute resolution of the Korean nuclear issues as long as both sides of the US and North Korea hold expectations for the future, cultivate mutual trust while keeping a contact and continuously negotiate related controversial issues.

As for China, it has recently proposed a national strategy of the two-century goals. China, as a rising great power, has no choice but to stress its relationship with both South and North Korea to prepare for the strategic competition with the dominating power, the United States, and undermine US regional influence in East Asia. How China's dilemma in its policy regarding the Korean Peninsula, in which China has to "maintain" and "manage" relations with both South and North Korea for its neighborhood diplomacy and relations with the United States, is manifested in its relations with the two Koreas (Shin, 2018). To realize this strategy, it is necessary for China to maintain a stable peripheral safety environment by keeping the good relations with neighboring nations including North Korea, South Korean and Japan, thereby being able to act as the stabilizer of the situation of the peninsula and the backbone force of resolving the Korean nuclear issues. In general, China sincerely encourages and favors the compromise of North Korea and South Korea/the US in dealing with the bilateral relations.

The multilateral cooperation-the final guarantee of the absolute resolution of the Korean nuclear issues.

Although the six-party talk, an attempt mode of the multilateralism failed to achieve any agreement, it should be pointed out that this functional failure is largely due to the huge disparity of the strategic purposes of North Korea and the US. In terms of North Korea, it demanded a direct bilateral talk with the US in order for the normalization of the North Korea-US relationship. Surely in the 
framework of the six-party talk, it can be expected to acquire the simultaneous promotion of the process of the normalization of the relationship of North Korea with the US as well as denuclearization. However, as one of the two predominant parties of the North Korean nuclear issues, the US was reluctant to shoulder the responsibility of the leadership in fulfilling the agreement and tried all its best to shirk its responsibility to China. Furthermore, the US refused to take any pragmatic procedures in promising not to invade North Korea and normalizing the relationship between North Korea and the US (Xu, 2011). For example, Terence Roehrig viewed that the combined conventional military strength of the U.S.-ROK alliance along with an uncertain nuclear umbrella is more than sufficient to deter a nuclear North Korea (Roehrig, 2017).

In view of the historical lessons and the present situation of the North Korea-US relations with some progress but inability to transcend the key link, it is time for China and South Korea to contribute their strength. Even with the difficulty to restart the six-party talk, China and South Korea should be made as the stabilizer to consolidate the situation of the Korean peninsula and resolve the North Korean nuclear issues. In particular, it is inappropriate to put China and South Korea aside while ending the armistice agreement and signing a formal declaration to end the Korean War. Even if the declaration to end the Korean War was achieved by the US and North Korea, it is doubtful for the enforceability and sustainability of this declaration in the circumstance of the lack of mutual trust of the US and North Korea.

\section{Conclusion}

In consequence, according to the development of the situation of the Korean peninsula since 2018 and 2019, it can be inferred that the future of the peninsula will be characterized by a state of an active bilateral interaction but a lack of the multilateral cooperation. After the repeated games of the bilateral relations of North Korea and the US/South Korea, it will be directed to the pursuit of a multilateral mode to resolve the Korean issues and stabilize the situation of the Korean peninsula. As said by Li Keqiang, China's prime minister in the annual report on the work of the government, the current world is facing a profound change of a kind unseen in a century. China will take a firm road of peaceful development, pursue a strategy of mutually beneficial opening up and resolutely uphold multilateralism and the international system built around the United Nations. Under such conditions, China should follow the trend and try hard to establish the multilateral cooperation framework at the basis of the active bilateral relations in Northeast Asia.

\section{Supported}

This Research is supported by Shanghai Municipal Planning Project for Philosophy and Social Sciences (2018BKS012). It is also supported by of the Nation Social Science Fund of China in the Later Stage (19FGJB004). 


\section{Conflicts of Interest}

The author declares no conflicts of interest regarding the publication of this paper.

\section{References}

Barrett, S. (2011). Rethinking Climate Change Governance and Its Relationship to the Word Trading System. The World Economy, 34, 1863-1882. https://doi.org/10.1111/j.1467-9701.2011.01420.x

Gu, W. J. (2019). The Moon Jae-in Government's Policy on the North Korea Nuclear Issue: Features and Dilemma. International Forum, 21, 125-139.

Han, R. D. (2018). The Evolution of the Korean Nuclear Issue Geopolitical Nature and Countermeasures. Theoretical Horizon, 1, 72-77.

Jervis, R., \& Rapp-Hoope, M. (2018). Perception and Misperception on the Korean Peninsula: How Unwanted Wars Begin. Foreign Affairs, 3, 103-117.

Jin, Q. Y. (2019). The Dilemma of the North Korean Nuclear Issue and the Response of the International Community. World Affairs, 14, 15-17.

Jun, B.-K. (2017). China's Sanctions on North Korea After Its Fourth Nuclear Test. Pacific Focus, 32, 208-231. https://doi.org/10.1111/pafo.12092

Kim, M.-H. (2017). Cracks in the Blood-Shared Alliance? Explaining Strained PRC-DPRK Relations in the Post-Cold War World. Pacific Focus, 32, 109-128. https://doi.org/10.1111/pafo.12087

Ko, S. (2019). International Sanctions on North Korea: A Two-Level Solution. Pacific Focus, 34, 55-71. https://doi.org/10.1111/pafo.12133

Lee, H.-O., \& Piao, L. G. (2019). On the Dual Transition of Chinese Diplomacy and Korean Peninsula Situation. Dongjiang Journal, 36, 29-34.

Li, C. R. (2019). China-DPRK Relations in the New Era: Changes, Motivation and Influence. Contemporary International relations, 12, 9-15.

Park, K.-A. (2010). North Korean Strategies in the Asymmetric Nuclear Conflict with the United States. Asian Perspective, 34, 18-34. https://doi.org/10.1353/apr.2010.0031

Piao, J. Y. (2014). The Evolution of the Situation on the Korean Peninsula Since the End of the Cold War. The Chinese Journal of American Studies, 28, 26-46.

Roehrig, T. (2017). The U.S. Nuclear Umbrella over South Korea: Nuclear Weapons and Extended Deterrence. Political Science Quarterly, 132, 651-684. https://doi.org/10.1002/polq.12702

Shin, J. (2018). China's Great Power Identity and Its Policy on the Korean Peninsula in the Xi Jinping Era. Pacific Focus, 33, 286. https://doi.org/10.1111/pafo.12119

Teng, J. Q. (2018). The Evolution and Choices of President Trump's DPRK Policy. Pacific Journal, 26, 81-86.

Turak, N. (2019). Trump Becomes First Sitting US President in History to Cross Border into North Korea. Breaking CNBC, 30 June 2019. https://www.cnbc.com/2019/06/30/rtrs-190630-trump-kim-quotes-dmz-eu.html

Xu, J. (2011). A Multilateral Security Cooperation Framework for Northeast Asia: Problems and Considerations. Journal of Contemporary Asia-Pacific Studies, 4, 92-106.

Yang, X. Y. (2019). The Origin and Development of the Korean Nuclear Issue and China's Policy towards the Denuclearization of the Korean Peninsula. Journal of Fujian Normal University (Philosophy and Social Sciences Edition), 217, 61-71. 
Zhang, D. D. (2019). Asymmetric Conflict: The Internal Logic of the U.S.-North Korea Interaction. Journal of Strategy and Decision-Making, 5, 35-56.

Zheng, J. Y. (2018). The Situation on the Korean Peninsula: Motivation, Assessment and Prospect. Contemporary International Relations, 5, 24-32.

Zhu, F. (2018). Winter Olympic Diplomacy-Historical Changes in Korean Peninsula? Contemporary International Relations, 3, 8-17. 